\title{
STYLE AND SOCIETY - ISTANBUL'S MUSiC SCEne IN THE 1960s AND 1970s: MUSICAL HYBRIDISM, THE Gazino, ANd Social Tolerance
}

\author{
Cornelia Lund and Holger Lund
}

\section{Introduction}

Like many countries all over the world, Turkey was hit by the first wave of Anglo-American pop-rock music in the 1950s and 1960s. Various styles of pop-rock were appreciated in Turkey; they were, however, not simply copied but combined with local, indigenous elements in many different ways. This led to the birth of musical hybrids, especially Anatolian Rock, Arabesk, and Belly Dance. The specific qualities of these combinations, that differentiated them from parallel developments in other countries, seem to be rooted in the unique situation of the Turkish music scene. Turkey had an independent music market with a large number of non-major and non-staterun record labels as well as a complex and autonomous musical tradition of combining foreign and indigenous elements. This had mainly to do with the people involved: they mixed and mingled, ignoring social boundaries to a surprising extent, producing musical syntheses consisting of unpredictable combinations and stunning turnarounds. The main place for this kind of musical practice was the gazino, a special venue somewhere between restaurant, concert hall, and nightclub, with its open-minded musical programming.

This article examines the acting agents and their styles, starting from selected musical examples and taking into account - aside from AngloAmerican pop-rock music and Anatolian Folk music - the three styles mentioned above: Anatolian Rock, Arabesk, and Belly Dance. Although each addressed a very different audience, these styles were freely combined, for example in Arabesk Rock as a mixture of Anatolian Rock and Arabesk. The main question for us will be: how was it possible that in Turkey apparently 
paradoxical combinations could come into being, which never could have happened in the Western world? Why would elements be combined that, according to the logic of pop-rock music, appear contradictory? It seems there was a special Turkish pop-rock logic at work, which had the gazino at its heart, this special location for Turkish hybridized music.

Our point of departure will be a short survey of the musical scene in Turkey in the 1960s and 1970s. We will have a look at the persons involved, the styles they played, and the extraordinary musical hybrids ${ }^{1}$ they constructed. These hybrids will lead us to the fundamental question for our research: how could they even be created, despite of the music-sociological paradoxes in style and audience? This article may not deliver final answers, but, hopefully, some outlines to be filled in by future research.

Much of the resurgence of Turkish rock and funk music of the first wave goes back to 2006, when hip hop-beat producer Egon ${ }^{2}$ compiled the "Stones Throw Podcast \#12«, the so-called »Turkish Funk Mix«, which for many of its listeners changed their perspective on the world of music forever. They found themselves listening to a stunning combination of familiar-sounding elements of rock and funk music and much less familiar-sounding elements of Anatolian music. ${ }^{3}$ The more so as Turkish rock and funk music were not mere copies of Anglo-American models, but themselves very distinctive hybrids of local and indigenous elements on the one hand, and global, Anglo-American elements on the other (cf. Skoog 2012: 3f.). This podcast pushed the interest in Turkish rock and funk music worldwide and many rereleases give proof of a continued interest until today. ${ }^{4}$

1 The term hybridization is becoming more and more common in scholarly literature on music. It is here used as defined in a previous text by author Holger Lund: $\gg$ The term hybridization is used in its biological sense, meaning something which is a product of two different species that have been crossbred. A hybrid is something consisting of different origins, transgressing the old order of the former species to build up something new « (Lund 2011).

2 Cf. http://www.stonesthrow.com/podcast (accessed 13.4.2015).

3 Gabriel Skoog said about this irritating listening experience: »One of the pleasures of list[en]ing to hybrid genres for the first time is the bending of frame involved as we re-orient ourselves in relationship to the piece (Skoog 2012: 91).

$4 \mathrm{Cf}$. the re-releases of Finders Keepers, who pioneered Guerrsen and Pharaway Sounds: http://www.discogs.com/label/38112-Finders-Keepers-Records, http:/ /www.discogs.com/label/105479-Guerssen and http://www.discogs.com/label /424574-Pharaway-Sounds (accessed 13.4.2015); or compilations such as the one curated by the author: V/A (2013). Saz Beat. Turkish Rock, Funk, and Psychedelic Music of the 1960s and 1970s. Ed. by Holger Lund. Corvo Records/ Global Pop First Wave, CGPFW 001. 


\section{The Field of Music in Turkey}

The Turkish Republic itself, as constructed by Kemal Atatürk and his chief ideologist Ziya Gökalp, was founded on the idea of combining East and West. Musically, this combination was realized by building hybrids of Eastern and Western elements. Not all of them were successful, but three styles in the 1960s and 1970s attracted large audiences: Arabesk, Anatolian Rock, and Belly Dance Music. ${ }^{5}$ These styles aimed at totally different audiences. Nevertheless, multiple hybrids between these three already hybridized styles took shape, in music and also in its visual, iconographic representation. For someone not familiar with the Turkish music scene, the paradoxical elements of these hybrids can be hard to disentangle.

To begin with: which style is which and how does it sound?

First: Arabesk can be translated as »made or done in the arabic fashion « (Özbek 1997: 185). It is regarded as a »Turkish version of Arab popular music « with »romantic melodies « and a »saccharinic, Bollywoodish « (Spicer 2011: 46) effect - at least this is how the leading British music magazine The Wire still puts it today, in a pejorative manner. Arabesk was already a hybrid construction, an East-West music. According to Martin Stokes, Arabesk originated as an sabsorption of a variety of Western popular and classical genres and performance styles into a [...] monophonic Eastern or Turkish form « (Stokes 1999: 123). This was also reflected in the wide array of instruments used: classical Turkish instruments like kanun and ney, Folk instruments like the saz, as well as drums, electric bass, electric guitar, piano, and Western string instruments (cf. Burhan Bayar in Bulut/Kaya 2010: 22:50-23:50 $\mathrm{min}$ and 31:31 $\mathrm{min}) .^{6}$

Second: the terms Anatolian Rock or Anadolu Pop were used by Turkish musicians to describe hybrids of Western pop-rock music of all kinds combined with Anatolian Folk music since the mid 1960s. ${ }^{7}$

5 With its similarities to Arabesk in status and Easternness Türk Sanat Müziği, a kind of classical, post-ottoman Alla Turka style, is not discussed here as a genre of its own, which of course it is (cf. Stokes 2003: 314). Moreover Anglo-American and European pop music were played in Turkey as well as Türkü, a sort of standardized folk song (cf. Skoog 2012: 61f.). All in all, these were the main styles one could hear during the 1960s and 1970s in Turkey.

6 The term »Western music « refers to a distinction made in Turkey between Alaturka and Alafranga: »Alaturka and Alafranga refer, respectively, to Turkish and Western socio-cultural practices«; for music this means »Turkish (Alaturka) and Western (Alafranga) style« (Beken 2003).

7 See Holger Lund's contribution »Anatolian Rock: Phenomena of Hybridization « to the conference »This Is the Modern World - For a Social History of Rock 
Third: Belly Dance music is music for erotic dancing and was for a large part produced for the Arabic and Turkish diaspora in the US (Thorne 2011). It was made by immigrants for immigrants and was a trend in music from the 1950s until the 1970s. ${ }^{8}$ Armenian and Lebanese musicians were also often involved in Belly Dance. During the 1960s the style was adopted in the Arabo-Turkish region via US imports and kicked off many local productions. Due to the influence of developments in US-American music, new instruments joined in: next to traditional Arabo-Turkish instruments, electrified, electric and electronic instruments as well as drum sets were integrated in the production of music. With the use of these instruments, we can consequently observe the emergence of hybrids of the traditional music of the Arab-Turkish region and pop-rock music.

\subsection{Examples}

In the following, we will analyze three pairs of tunes to get a more thorough insight into the musical situation in Turkey at the time.

Pair 1: Orhan Gencebay - »Hor Görme Garibi« (1971) and

Erkin Koray with Ter - »Hor Görme Garibi« (1972).

Orhan Gencebay's piece is a typical Arabesk tune: the song is slightly electrified and sounds a bit Western, but the arrangement of the violins and the vocals are still dominated by the tradition of Arabesk music. The same tune was re-worked one year later by the Anatolian Rock musician Erkin Koray and the group Ter, still under the title »Hor Görme Garibi«. Compared to Gencebay's original, quite a few things have changed: Koray electrifies and Westernizes the sound, especially the vocals that, even if they still follow the Arabesk melodic line, get an extra touch of scream, which is so typical for Western rock music. Koray injects a great portion of hard rock into the Arabesk tune, thus building a hybrid between the two styles.

Music«, Université Charles-de-Gaulle Lille 3, Lille. According to this analysis, the term is $\gg$ not bound to Anatolians playing rock music, but used as an umbrella term for all sorts of music which combine different styles of Western pop and rock, psychedelic, funk, disco, progressive, folk, and so on with Anatolian folk music« (Lund 2013).

8 Of course belly dancing and its music have a much richer history. It was not just an American nightclub entertainment invention exported to the Middle East, but a whole culture with a specific history in Turkey, a phenomenon in Egyptian films, and a dance-entertainment culture of several different regions (cf. Oyku Potuoglu-Cook 2008). The focus in this text is on Belly Dance as a hybridized genre mixing traditional with electrified, electric, and electronic instruments. 
Pair 2: Orhan Gencebay — »Bir Araya Gelemeyiz« (1975) and Erkin Koray - »Sevdiğim« (1976).

Another track by Gencebay, »Bir Araya Gelemeyiz«, is an Arabesk tune with the intro played in a hard rock manner, featuring a rock synthesizer and a typical rock riff or lick. Here we have an Arabesk musician playing a hard rocking Arabesk tune. The next piece is again by Koray: "Sevdiğim« from 1976. This tune works in the opposite way: it is an Anatolian Rock tune done in an Arabesk manner, easily recognizable from the string section.

One might use the term Arabesk Rock to describe these kinds of hybrids presented in pair 1 and 2, to differentiate them from Anatolian Rock as well as Arabesk. Another example for this sort of Arabesk Rock would be Hakki Bulut's »Nedir Bende Olmayan« (1975). It has no string section but a combination of pop-rock guitar, partly straight rock beats by drums and bass, and Arabesk singing along with saz playing.

Pair 3: John Tatasopoulos - »Bouzoukia solo« (1975) and Cem Karaca - »Demedim $\mathrm{Mi} \ll$ (1971).

The next two musical examples show that not only Arabesk and Anatolian Rock are subject to hybridization, but Belly Dance as well. The tune »Bouzoukia Solo « by John Tatasopoulos comes from the US-released LP Alla Turka, alternatively named Music For Belly Dancing - The Turkish Way With Özel (1975). »Bouzoukia Solo « is not, as one may think, simple Belly Dance music: it is a Belly Dance-Anatolian Rock hybrid, with an electric wah-wah bouzouki imitating an electric saz, an instrument developed in reaction to the electric guitar of rock music which became very popular in Anatolian Rock music. The fact that the non-Turkish musician John Tatasopoulos plays the non-Turkish instrument bouzoukia should be held against the fact that the title of the LP, in each version, suggests Turkish music, which indicates the typical melting-pot situation in the US, with non-Turkish people from Armenia, Greece, or Israel regularly playing Turkish music (Thorne 2011).

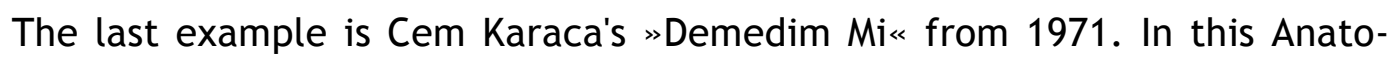
lian Rock-Belly Dance hybrid a rock group is playing a continuous Belly Dance line in the percussion and bass, which is extended and accentuated by a long Belly Dance break in the middle of the tune. 


\section{The Complexity of the Situation}

These examples give a good idea of the complexity of the musical situation in Turkey. Styles that are already hybrids themselves, are combined to form multiple hybrids. The number and variety of these hybrids, the fluid and surprising combinations within them, are simply astonishing. In this aspect, by the way, the musical production of Turkey differs from that of comparable post-ottoman countries. In the unexpected combinations of styles, the unusual instrumentations, the stunning arrangements and compositions, Turkish hybrid music shows complete autonomy (Skoog 2012: 29f. and 34).

When we search for the reasons of this development, we find different contributing factors. On the one hand, there is the specific situation of Turkish culture and its historical development, which we will analyze later on. On the other hand, the particularities of the Turkish music economy have to be taken into account. Different to most other non-Western countries, the Turkish music market was neither dominated by globally acting major labels, working as hegemonial gatekeepers, nor by nationally acting state-run or state-controlled labels, dominating the national production, but instead by many smaller or bigger independent labels, some of them lead by Turkish musicians. ${ }^{9}$ Compared to other countries, the music production was relatively uncontrolled and unregulated. A homogenization of the market by major or state-run labels did not take place in Turkey in the first decades of pop music. ${ }^{10}$

Gabriel Skoog (2012: 24) also mentions that the Turkish Republic, especially Istanbul, »never felt the direct long-term effects of European colonialism«. Thus, Turkey's autonomy was unbroken by colonial power structures. The latter normally would set the cultural standards, imposing them on the colonized people, engraving in their minds which »developed« standards

9 The number of Turkish labels was extraordinarily high in the 1960s and 1970s. To our knowledge there exists no compendium listing them all. After years of research in vinyl record stores one will still discover more and more labels from that period. We estimate that about 50 to 70 independent labels have existed in Turkey. Some of the old ones are still active and are located at iMÇ (İstanbul Manifaturacılar Çarşısı), Unkapani, Blok 5 and Blok 6 in Istanbul.

10 As far as the authors know, in the same period of time only the musical panorama of Pakistan showed a similar complexity concerning combinations and unpredictable musical developments in songs - despite the fact that the music market in Pakistan was dominated by only a very few major labels. The reasons for the complexity of the situation in Pakistan, however, still have to be explored. 
should be adopted and which more »primitive« ones should be devalorized and erased. This did not happen in Turkey. ${ }^{11}$

\subsection{Arabesk vs. Anatolian Rock (?) vs. Belly Dance (?)}

Most noteworthy about the complex situation in Turkey is that it really should not exist, considering the music-social frontiers valid especially in the Western world. Apparently contradictory elements were put together in musical practice, were freely combined and hybridized. But first of all, what exactly do we mean when we speak of contradictory elements?

Arabesk had, outside its audience, a very bad reputation in Turkey. This had to do with the audience itself: poor, little educated, mostly Anatolian immigrants and workers in the periphery of the big cities like Istanbul. Arabesk was called »Minibus music ${ }^{12}$ or also »Migration music ${ }^{13}$. It was considered by the urban, well-educated middle class as uncultivated, imitative (being Arab-like), pre-modern and non-Western (cf. Stokes 2010 and Köksal 2012). A typical audience can be seen in the film Derdim Dünyadan Büyük (1978), which shows Arabesk musician and actor Gencebay with the poor people that formed his fanbase.

While we might view Arabesk as a »domestification of an international soundscape [...] presenting it for a Turkish audience $«$, as Stokes (1999: 135) does, Anatolian Rock on the contrary can be regarded as »internationalizing a local music, connecting it to the international counterculture (ibid.). ${ }^{14}$ Proof of this is found in photos like the one showing Koray (on the right)

11 Skoog emphasizes that Turkey »was never colonized by a European power «. Therefore, Turkey is an autonomous »competing aesthetic center « to him (Skoog 2012: 151).

12 Orhan Gencebay in Bulut/Kaya 2010: 37:31 min.

$13 \mathrm{Cf}$. Orhan Gencebay in ibid., 15:44 min and 28:32 min.

14 It is interesting to note that Skoog, in opposition to Stokes, sees it just the other way round: "Anadolu Rock can be understood as a local music scene which first grew out of a large, mass-mediated, translocal scene, but with time turned into its own local phenomenon. « His explanation: »Anadolu Pop artists combined genre cues to create a new style which would appeal to a local audience, and it was the positive response to this localized style which kick started a local Anadolu Rock scene. « Therefore he concludes: »Anadolu Pop is a localized global genre (Skoog 2012: 162f.). Both views may be correct. Depending on the point of view one can define Anatolian Rock as the localization of an international music or as an internationalization of a local music. Skoog himself shifted his point of view: »Anadolu Pop artists such as Mogollar, Barıș Manço, and Cem Karaca all attempted to have an effect on the larger global rock scene through participation in the European market. Indeed, Barıș Manço went as far as to release an English language album« (Skoog 2012: 164, cf. also 168f.). 
together with John Lennon and Yoko Ono in $1971,{ }^{15}$ exemplifying a certain affirmative orientation towards Western modernity.

Visually, Anatolian Rock stations itself either as pro-rural, ${ }^{16}$ such as the group Moğollar who pose in rural costumes for the cover of their single Cığrık ${ }^{17}$, or it demonstrates urbanity, which could even take quite radical aspects, as in several photos of Koray naked with an electric guitar. ${ }^{18}$

Politically, the two stylistic positions are also drifting in opposite directions: despite of some rebellious attitudes, Arabesk music is mainly shaped by a rather conservative, fatalistic belief in a paternalist-hierarchical way of life (cf. Bulut/Kaya 2010), whereas Anatolian Rock with two of its main agents, Selda Bağcan and Karaca, shows not only a democratic, but rather a left-wing revolutionary orientation (image 1 and image 2). An intermingling of the two audiences, the Arabesk and the Anatolian Rock audience, should therefore never happen according to the logics of music sociology.

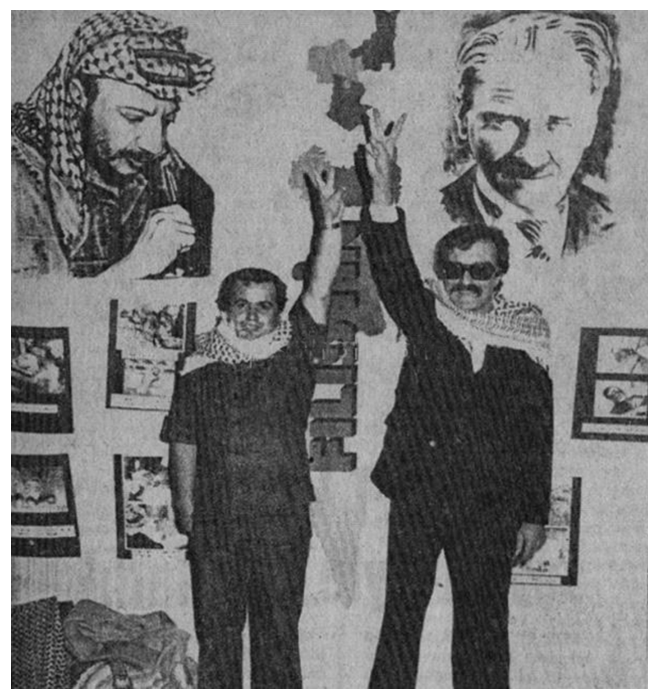

Image 1: Cem Karaca, PLO, no date.

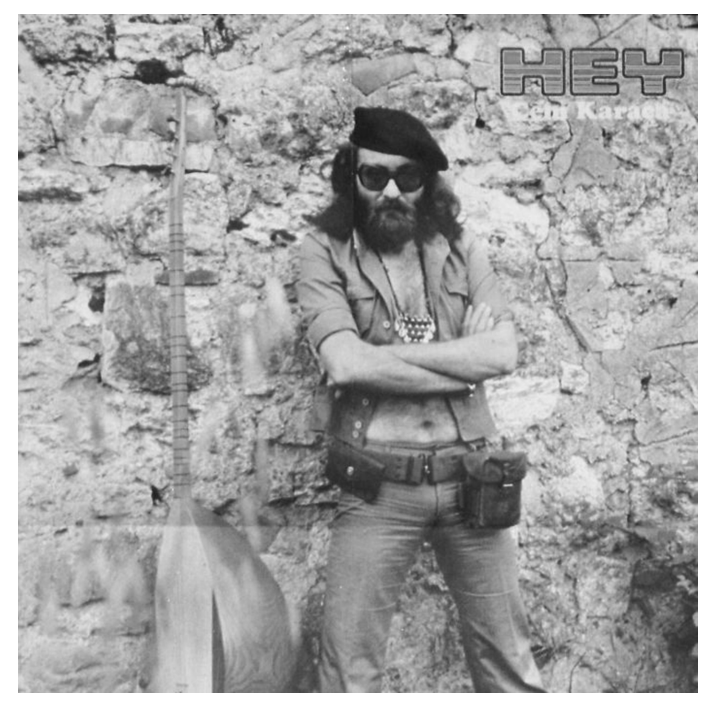

Image 2: Cem Karaca as featured in the Turkish 1970's music and youth magazine Hey, no date.

15 Erkin Koray with John Lennon and Yoko Ono, 1971: https://touringinstability. wordpress.com/2014/01/22/erkin-koray-the-grand-magus-of-turkish-psych (accessed 13.4.2015).

16 This is also obvious in the typical musical relation of the Türkü with the rural. The Türkü are transformed Anatolian, hence rural, folk songs (cf. Skoog 2012: 61).

17 Cover for Moğollar - Cigrik (1972): http://www.discogs.com/Moğollar-ClğrıkSila/release/3486592 (accessed 13.4.2015).

18 Cf. http://braden4dbraden.nm.ru/erkin-koray.html, http://barisakbali.tumblr. com/post/64209189015/anadolu-rock-ve-hard-rock-turunde-ozgun-eserler and http: / /alkislarlayasiyorum.com/icerik/141521/erkin-koray-insanlari-ciplakligadavet-etmek-21-haziran-1970 (accessed 13.4.2015). 
Moreover, the visuals of Belly Dance record covers, the explicit (semi-) nudity of the women (images 3 and 4), is not compatible with either the more conservative Arabesk audience or with the democratic left-wing audience of Anatolian Rock. But nevertheless, a single by 4 Oyun Havasi offers a cover version of Koray's »Fesuphanallah«, turning his Arabesk Rock into an instrumental Belly Dance Rock. Here again we are in a realm where all things are combined and mixed, even if they - according to the common music-social point of view - should be kept separated.
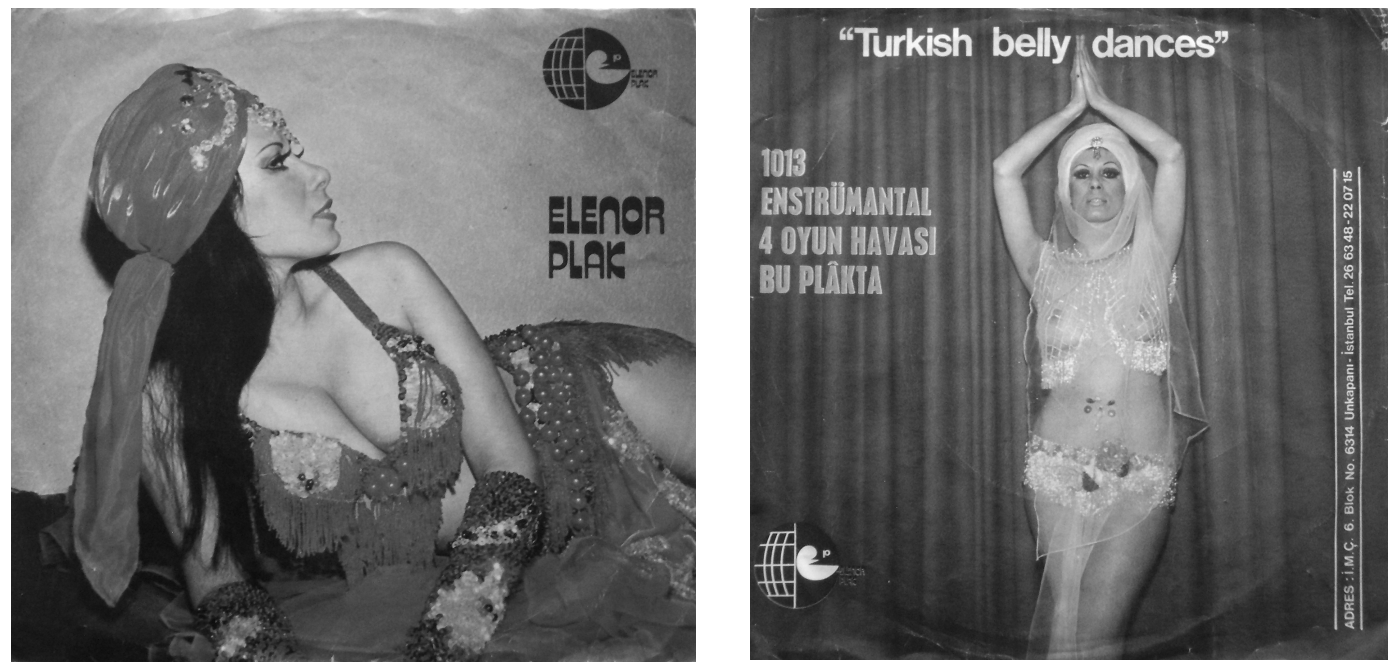

Image 3 and 4: Cover for 4 Oyun Havası, Turkish Belly Dances, recto \& verso, ca. 1976.

The phenomenon continues visually, defeating every potential conflict: a photo from 1976 shows Gencebay and Koray during a jam session (image 5). Koray presents himself as an urban Anatolian Rock musician in jeans, with long hair and a cool sitar beat instrument. ${ }^{19}$ Gencebay, however, appears as an Arabesk musician, with mustachio, spick-and-span white trousers, and a very traditional, non-electrified saz. Another photo again shows Gencebay, now with Barıș Manço, in 1972. Against the correct suit of Gencebay, Manço wears a rural belt with a tied knot (image 6).

19 The sitar, seen in its stylistic and semantic aspects, probably did not come directly to Turkey from Asia but indirectly via Great Britain (just think of the George Harrison-initiated sitar beat boom). Consequently, the sitar is in this context primarily a Western sitar beat instrument and not a classical Eastern instrument. 


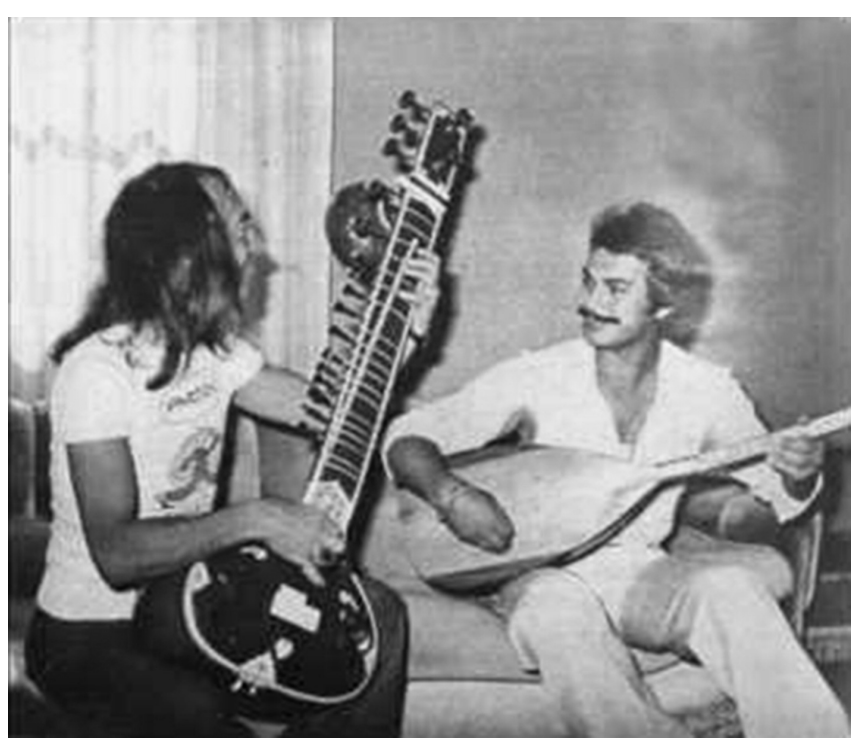

Image 5: Jam session with Orhan Gencebay and Erkin Koray, 1976.

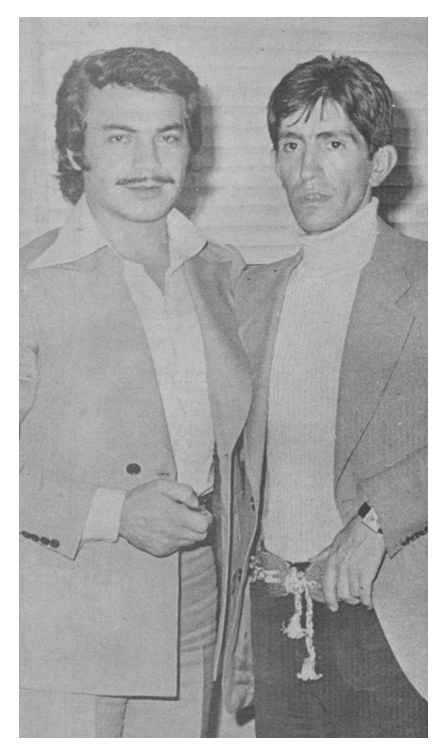

Image 6: Orhan Gencebay and Barıș Manço, 1972.

Some magazine photographs move another step ahead: on a cover page probably published in celebration of a musical contest in 1972, Gencebay, the Arabesk star musician, is placed among part of the elite of Anatolian Rock musicians: Manço, Bağcan, and the three Hürel brothers (image 7).

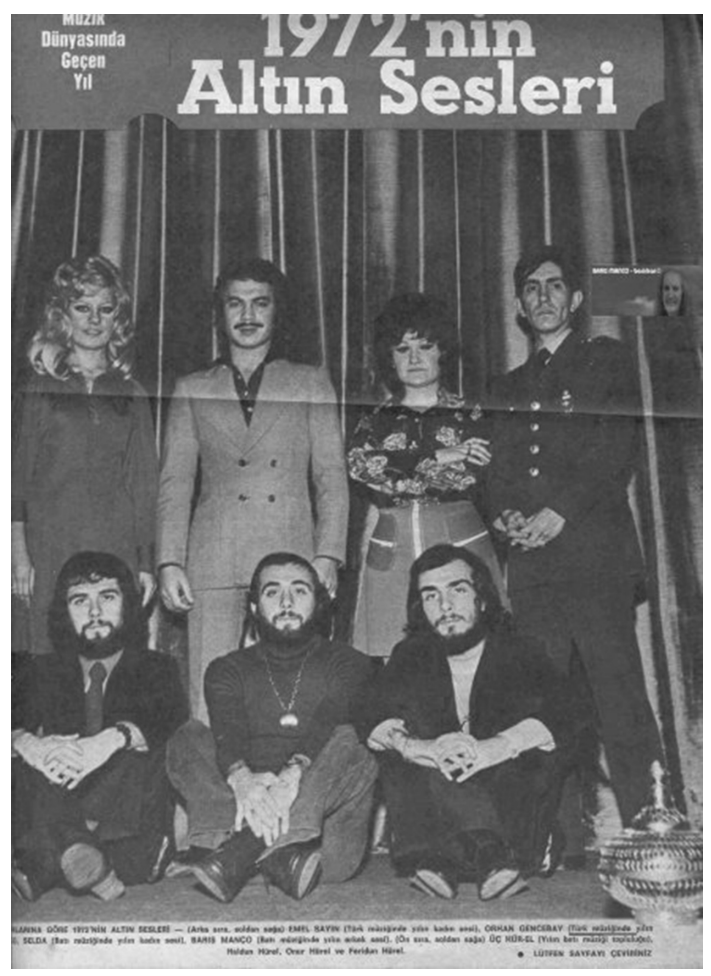

Image 7: Cover of a magazine with Orhan Gencebay, Barış Manço, Selda Bağcan and the three Hürel-brothers, 1972. 
Another, similar photo made in $1971^{20}$ shows Manço, Karaca, and the group Moğollar together with star singer Zeki Müren, who plays Türk Sanat Müziği, like Arabesk a popular Eastern style (cf. Stokes 2003: 314). Müren appears again in an undated group portrait ${ }^{21}$ next to Karaca. Given the sociological differences between the musicians, such photos are an extension of what is happening in the music itself, the paradoxical but nevertheless practiced musical hybrids or multi-hybrids. ${ }^{22}$

How could this happen? And did the Turkish people back in the day also regard and experience these hybrids as paradoxical? In the following, we will try to give some answers to this question.

As we have mentioned, an intermingling of these audiences would not have been possible according to Western music-sociological thinking. The main reason, as Diedrich Diederichsen recently explored in depth, is that from the 1950s to the 1990s pop music has been used in the Western world as a means to differentiate identity, to express different political and social attitudes. The decision to adopt a certain style (and the attitude related with it) implied always the negation, even radical negation and non-acceptance, of all other styles (and attitudes related with them) (Diederichsen 2014: passim). If such very different things come together, as in the musical and photographical examples mentioned above, there must have been some shared fundaments as common ground.

\subsection{Shared Fundaments and Where They Came From}

It is useful to consider the parameters shared collectively by the three styles. All of them, Arabesk, Anatolian Rock, and Belly Dance, were allowed to be practiced by the state authorities, but were not supported by them at all. The national radio barely played the songs of any of these styles. ${ }^{23}$ They were treated as outsider music, although for different reasons. All three styles were related to Anatolian Folk and Türkü and therefore had a common musical fundament. This important fundament should not be over-

20 Barıș Manç, Cem Karaca and Moğollar together with Zeki Müren, 1971: http:// twicsy.com/i/SuRdZd (accessed 13.4.2015).

21 Group photo with Cem Karaca next to Zeki Müren, no date: http://www. ilkogretim.info/?attachment_id=4075 (accessed 13.4.2015).

22 Indeed, there exist musical pendants to the photos discussed above (images 5 to 7): Barıș Manço, for example, played »Aglama Degmez Hayat« (1969), a famous tune of Türk Sanat Müziği, which Zeki Müren recorded in the same year. Or think of the musical pairing we have analyzed in chapter 1.1 .

23 Cf. Kadir Çöpdemir, in Bulut/Kaya 2010: 6:28-7:11 min., and Stokes 1999: 123. The Turkish Radio and Television institution TRT published only two Anatolian Rock records over all the decades, »TRT Ara Müzikleri« I and II. 
looked, as the use of a shared musical tradition has a strongly connecting effect (which is not easily understandable from a German perspective, for example, where the Volkslied after being commonly abused by the Nazis in general died, morphing into the genres of schmaltz or schlager afterwards).

Considering the massive social differences of those involved, however, these commonalities are not strong enough to explain the photographs and musical hybrids. One may suspect that it was all about money and that musical hybrids addressed a crossover audience to widen the market. However, this would have meant committing a sort of musical hara-kiri, just as if, in those days, someone had combined German schlager singer Heino with hard rock to enlarge the target group. Today, in our post-modern era, this works well, as the very example of Heino shows. In the much more strictly modern era of the 1960s and 1970s, when social identity was constructed with and by the use of differentiating musical styles, these kinds of hybrids were definitively unthinkable in the Western world - but were apparently possible in Turkey as the examples above show. Instead of a hara-kiri a special solution has been developed to which we will come back later on.

Another idea suggests that the elite of session musicians in Turkey was so small and so limited in its access to electric and electronic gear as well as in its competence to use it, that this small group of people had to play all styles. ${ }^{24}$ Admittedly, session musicians will be hired for any job in any style; that is how they are defined. But anywhere else these musicians do not hybridize musically and visually in public, they do it behind the scenes, in the studio, in secret. Otherwise they would hurt their public musical identities, their image on the market. Both the schmaltz guitar player and the hard rock guitar player would mutually destroy themselves if they showed up in personal union. They have to stay separate in the public space, stay different, this is their proper function in order to build social identities and possibilities for identification for their audiences.

Another approach to the question can be found in Cadğas Uyar's liner notes for the Bunalım re-release (Uyar 2006). He posits that some of the songs by the group Bunalım can be seen as a proof of an interest in nonhybridized rock, taking Anglo-American productions of the time as a model. What prevented them and all the other Turkish musicians from following that model was the specific music-political situation. The latter was marked by repression, and fear of repression, concerning non-Turkish music on the one side, and acceptance of, as well as support for, hybridized Anatolian

24 Which is indeed true and can be easily observed looking at the credits on the covers of completely different music styles: the same names appear all the time. 
Rock music on the other side, starting with the big pop music contests by Hürriyet and Milliyet in the mid 1960s (cf. Lund 2013).

The tendencies to support hybridization can be traced back to the founder of the nation, Kemal Atatürk, and his chief ideologist Ziya Gökalp. They initiated and supported a new hybrid East-West music for the new Turkish republic, a kind of a modernized and Westernized version of Anatolian Folk music (ibid., cf. also Erol 2010; Tekelioğlu 2001). Stokes calls Gökalp's concept a »nationalistic cosmopolitanism« (Stokes quoted by Burkhalter 2012: 44). He sees it as a part of the music-political strategy of the state, leading to an amalgamation of indigenous Turkish and Western music. »Nationalistic cosmopolitanism « may sound paradox, but the term very precisely describes the national point of view from which a hybridist cosmopolitan point of view was developed. Hybridization then had become the standard, and consequently non-hybridized music was not much in favor. Therefore non-hybridized pop-rock music was only seldom released.

Yet we still do not know how the musical hybrids and multi-hybrids could be realized, despite the fact that they were violating the borders of social identities. The audiences themselves were keen on differentiating one from another. None of the urban, middle-class citizens would ever share the same cultural space with the poor, rural immigrants of the gecekondus (informal settlements in the periphery of the big cities). And vice versa, no immigrant would dare to show up in an urban cultural audience, his clothing and manners would have betrayed him instantly as belonging to another social context. So what seemed to be impossible in real life was realized and practiced in music.

Next to the idea of a collectively shared traditional musical fundament it could be helpful to have a closer look at how one of the audiences would see the other. For the democratic left-wing people of Anatolian Rock the immigrants listening to Arabesk appear in a positive light, as they fit with their pro-rural tendencies (most of the immigrants coming from a strongly rural background), and the moments where lyrics of Arabesk music expressed critical views on the circumstances of life were appreciated. Politically, Arabesk music was not per se strictly conservative, differentiations must be made here in many directions (cf. Bulut/Kaya 2010, Stokes 2000, Doğtaş/Labastida 2014). Furthermore, Arabesk music was related to the workers and (ex-)farmers, which was the part of the population that democratic politics focused on. 


\subsection{The Gazino}

Yet perhaps the most important key to the whole situation is the gazino. It was a very special location, existing mainly in Istanbul (Beken 2003) and Izmir, which brought the different audiences, working and the urban middle classes, together in one place. From the musical point of view, it was a very open urban venue for entertainment, something between a restaurant, a show and concert hall, and a nightclub. The gazino culture, consisting basically of East-West music performed within a Western architectural frame, started in the 1930s and ended in the 1970s (image 8 and 9). Clearly the gazino helped to establish the aforementioned multiple musical hybrids between the three styles. Their owners, driven by commercial interests, changed the paradigm: what elsewhere in the world of pop-rock music had been separated as (life-)styles and opposing identities, was thrown together in the gazino, musically and in the visual aspects related to the music.

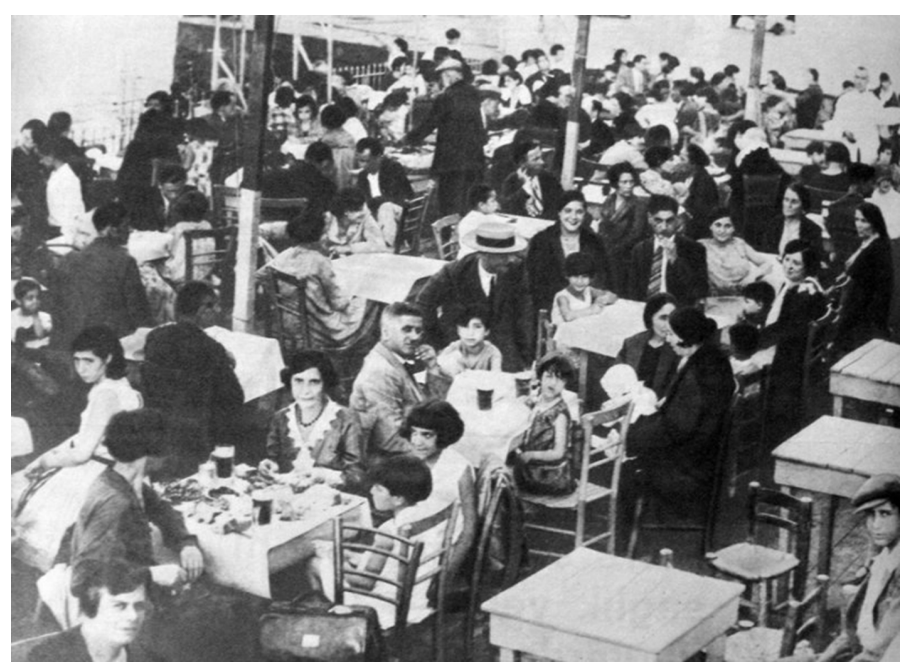

Image 8: Interior of an early gazino, Istanbul, 1931.

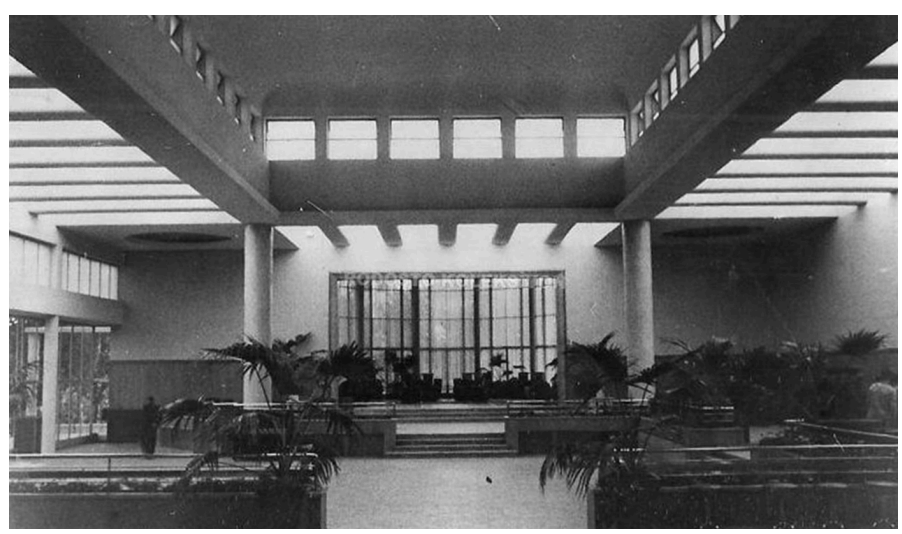

Image 9: Interior of the Taksim Belediye Gazino, Istanbul, 1960. 
The venue served as a point of intersection for different audiences. Gazinos were places where citizens, landowners, farmers, and workers came together under the sign of a collectively shared Anatolian musical fundament. ${ }^{25}$ And it did not matter that Anatolicity for each audience meant something very different: whereas Anatolia was the lost home, but still the heart of their identity for the rural and ex-rural Arabesk audience, it was a concept promising a more natural identity for the urban Anatolian Rock audience, an object of a certain turko-rural longing.

Münir Nurettin Beken explains the musical fluidity of the gazino as follows: the "gazino always reflected the taste of the paying customers. Therefore, the impact of changing demographics and aesthetics of society has always been reflected on the gazino show and its physical space « (Beken 2003). Depending on the owners and audiences, everything could take place in the music: Arabesk, Belly Dance, Anatolian Rock and Pop. ${ }^{26}$ This is reflected by the fact that the gazino usually had different orchestras: at least one Arabesk orchestra and one pop orchestra for the same location were the standard. Members of these orchestras could meet each other, for example in back-stage concerts. ${ }^{27}$

When programming the gazinos, the owners were primarily focused on their audiences and their heterogeneity: „Expectations of the consumers from all the different domains are fulfilled by the management at big gazino-s [sic!] (ibid.). This heterogeneity is worth taking a closer look at:

25 »The Turkish musical scene may be viewed in terms of three categories: alatürka, which refers to Turkish sociocultural practices; alafranga, which refers to Western ones; and arabesk, which denotes the culture of peripheral urban immigrants. The gazino, a type of nightclub, provides a common denominator for alatürka and arabesk music in an alafranga space« (Anon. 2011). Beken notes: »While the program indicates connections with Ottoman institutions like coffeehouses and meyhane-s (a restaurant type), the gazino space itself resembles earlier Western style establishments in Istanbul. The variety show is one of the determining aspects of the gazino program and it probably goes much further back in history « (Beken 2003). The main period of the gazino is 1930-1980: $\gg$ The advent of television and economic fluctuations since the 1970 s caused a steady decline for the business of gazino. The glamorous large gazino-s of the mid-twentieth century Istanbul disappeared « (ibid.).

26 Cf. ibid. and old gazino programs: http://turkiyeningazinotarihi.blogspot.de, http://turkiyeningazinotarihi.blogspot.de/2012/12/1976-ylnda-istanbul-gazinoprogramlar.html, http://turkiyeningazinotarihi.blogspot.de/2012/12/gazino-sa vaslar-1976-1.html and http://turkiyeningazinotarihi.blogspot.de/2012/12/gazi no-savaslar-1976-2.html (accessed: 13.4.2015).

27 According to Beken the back stage was also a place for music theory and discussion (cf. Beken 2003). 
»At the beginning of the twentieth century [...] gazino customers were Turkish intellectuals and non-Muslims of the Beyoğlu district of Istanbul. After the foundation of Turkish Republic, Turkish intellectuals and statesmen continued to be regular customers of gazino« (ibid.).

After World War II, two new audiences came to visit the gazinos, rich landowners from the countryside and formerly poor farmers, which had immigrated to the big cities and made a fortune there. Beken notes:

»This societal shift was reflected in the addition of the Folk Music as a fabricated urban genre into the gazino repertoire (ibid.). Accordingly, Folk music orchestras were established. The social climbers pushed the change to Arabesk music: »As soon as they could afford it, former gecekondu inhabitants became part of the frame of gazino customers. Their consumption of Arabesk music [...] was also reflected later in the gazino show « (ibid.). In addition to the evening program, affordable matinees were offered for »middle-class families from a variety of backgrounds with a regular limited income $\ll$ (ibid.).

The crucial point was the heterogeneous programming the owners proposed: "The music, like the food, is presented as a fixed menu. [...] An individual who comes to a gazino to listen to and experience the show of, say, an Arabesk star, by necessity ends up tolerating other genres « (ibid.). And so the public had to eat the whole »menu«: all the gazino genres like »Fasil [ottoman classic], Turkish Art Music, Folk Music, Arabesk, Turkish Pop Music, Belly Dancing and Comedy« (ibid.). Beken concludes:

»Changes in the gazino show are related to changes in sthe code< carried by the consumers. Political, economic and social changes superimposed radical changes in the aesthetics and resulted in aesthetic islands in the map of the Turkish society« (ibid.).

Indeed, with all variety of the genres allowed and mixed, the gazinos were »aesthetic islands « in Turkish society. A last crucial point was the social coding of the music:

»Certain parts of the gazino show reflect [...] two types of power. While Arabesk reflects economic power, traditional genres like Fasil or tango reflect the social prestige of Alaturka and Alafranga. An individual's economic power may buy the best seat in the gazino; social prestige, however, still comes with one's interest in more traditional genres, such as the Turkish Art Music. The gazino consumer gets educated by tolerating other genres that have historical dimensions« (ibid.).

Beken shows that the gazino was constructed to have a pedagogical function toward tolerance, insofar as visitors wanted to combine economic power, 
coded in hybrid genres with Western elements, with social prestige, coded in traditional Turkish genres. They could achieve that only by tolerating all the different genres.

The architecture also had an effect of reinforcing the tolerance of the public. Beken describes it as follows (image 10):

»The Caddebostan Maksim Gazinosu (CMG) was situated in a modern building with a parking lot. Its modern exterior architectural design was similar enough to a Western fine art gallery or institution that it could be characterized as an Alafranga space« (ibid.). ${ }^{28}$

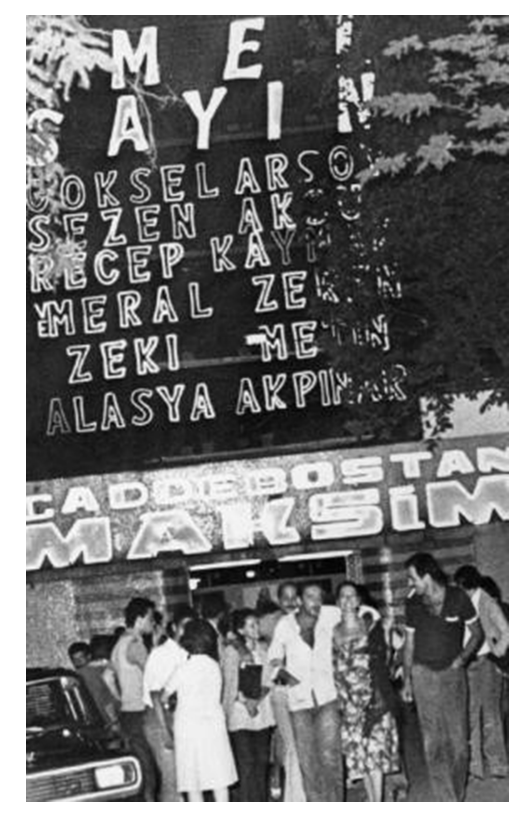

Image 10: Caddebostan Maksim Gazino, Istanbul, 1981.

The architecture marks a clear statement for modernity and social climbing: »The gazino transports the audience [...] to a high status. The Western cultural codes conveyed through the visual arts contribute to this illusion created for them « (ibid.). This continues in the medial and spatial context of the gazinos, which itself has a pedagogical effect on the public:

28 Beken continues: "The cream-colored columns, moldings, niches, cornices, and other architectural ornaments were reminiscent of classical Western architecture, although the use of geometrical shapes in the exterior was closer to Art Deco. There were also a few windows, some of which had stained glass with modern-looking Art Deco designs. Further evidence of Western influence could be found in the CMG's interior, with its Art Nouveau-style wooden picture and mirror frames, the bronze sculptures, light fixtures, vases, stained glass, paintings, classical Greco-Roman style columns, moldings, cornices, and whitecolored sculptures in illuminated niches« (Beken 2003). 
»The newspaper advertisements, and neon lights in front of the gazino help foster this illusion. The audience's preferred clothing, make-up and other behavioral changes reflect their efforts to adapt themselves to this atmosphere« (ibid.).

The atmosphere created this way could be described with Negri and Hardt's term as »multitude « (cf. Hardt/Negri 2000), a multiplicity and variety of persons and styles. And exactly this character of multitude was a requirement for the gazino to become what it was: a place that lead musicians and audiences to musical hybrids and tolerance, bridging over their differences. Of course there was still a lot of conflict going on, mainly between the owners of the gazinos as artistic directors and the musicians (cf. Beken 2003). The multitude was not the basis, but the result of a continuously ongoing process of negotiation between owners of the gazinos, the audiences, and the musicians.

In the 1970s, the Turkish music magazine Hey had a similar effect in combining and developing tolerance. Comparable to the German Bravo, to which Hey in the beginning saw itself as an equivalent, hit lists mixed international pop music stars with local ones, in this case Turkish Anatolian Rock musicians. Unlike Bravo, Hey had a separate hit list for Arabesk, Türk Sanat Müziği, and Türk Halk Müziği, which mostly ran under the term »Türk Müziği«. And all the musicians - regardless of their style - got reports in the magazine. Sometimes a tune like »Zühtü« appeared in both hit lists, once in the funk version by Esin Afșar (list »Hey Disko«), once in the folk version by Bedia Akatürk, and once in the Arabesk version by Șenay Șenses (both on the list »Türk Müziği«) (Hey 4:7, 1976: 4 and 9). A singer like Neșe Karaböcek could appear, according to her different styles (pop and Arabesk), in the same magazine in both hit lists (Hey 51:3, 1973: 4f.). Or she could appear even with the same pop-Arabesk hybrid tune »Demiyom mu« in the same magazine in both lists (Hey 29:4, 1974: 4 and 67).

For both Anatolian Rock as well as Arabesk or Türk Müziği record releases, ads were placed, even directly following each other. Attitude and intentions of Hey would need further examination. As Hey belonged to the Milliyet media group, the same forces, which pushed the Altın Mikrofon contests in the 1960s towards Anatolian Rock could have been at work (cf. Lund 2013). In any case: Milliyet in the 1970s promoted contests like »Türkiye Liselerarasi Müzik ve Halk Oyunlari Yarișmasi «, which combined sections of rock music with sections of traditional folk music (cf. Hey 10:4, 1974: 20). So Hey, like the gazino, functioned as a place for different musical styles and their audiences, bringing them together and promoting tolerance. 


\section{The Turkish Pop Logic}

To sum up: apart from the Kemalistic hybrid-friendly music politics there are three main arguments to explain the building of hybrids in Turkey: a collectively shared musical fundament (Anatolian Folk music), a collectively shared political fundament (rebellious left-winged), and a collectively shared space (the gazino in three-dimensional architecture and Hey in twodimensional print). Not on their own, but connected and interacting, an exploration of these overlaps may lead to an explanation for the hybrids and multi-hybrids one can hear and see in music and the accompanying materials.

The Turkish pop logic then could perhaps be described at its core as a logic of multitude, which has the power to put together what elsewhere, especially in the Western world, would seem to be a music-social paradox, a conflict of identity. The way to this logic of multitude was opened up by two main elements: on the one hand by the Turkish Republic's version of modernity, the »nationalistic cosmopolitanism « (Stokes), which functioned as a stepping stone for stylistic combinations between East and West, and on the other hand by the gazino with its commercially driven programming, opening the way - and space - for audience tolerance, which was additionally supported by magazines like Hey.

Antoine Remise recently came up with a surprising idea:

»In a way, >Anatolian Rock` was more an easternization [sic!] of Turkish music trends than the westernization [sic!] that is usually discussed. The bands and artists started to copy less and less their Anglo-Saxon models and developed their own genre. The audience's response was huge; their amazing and unique melodies had a fresh energy that touched the hearts and minds of many who wanted to be a part of the bigger modern world whilst enjoying their Turkish identity« (Remise 2014).

This is a complete change of perspective - seeing Anatolian Rock as an Easternization of Turkish music -, but perhaps much closer to the Turkish pop logic as a viewpoint from inside this logic. So it was Anatolian Folk music to which an already Westernized Turkish youth started to turn in its quest for identity (cf. ibid.). ${ }^{29}$ This twist in thinking is perhaps neither a

29 Historically, one could see it this way: Turkish rock music started in the late 1950s with copies of Anglophone songs, continued with Turkish versions of them, and then, with Tülay German's »Burcak Tarlasi « (1964), which features Turkish folk music with Western instruments, Anatolian Rock was invented (cf. also Skoog 2012: 3 and 116f.). 
contradiction of Stokes (1999: 135), who sees Anatolian Rock as »internationalizing a local music, connecting it to the international counterculture ", nor of Skoog (2012: 162f.), who regards Anatolian Rock as the localization of an international music. The Turkish pop logic contains several perspectives, including them all, not excluding one or the other. It is a logic of multitude, again.

\section{Bibliography}

Anon. (2011). »Gazino Aesthetics. «In: Bibliolore. The Rilm Blog (Répertoire International de Littérature Musicale), http://bibliolore.org/2011/07/17/gazinoaesthetics (upload: 17.7.2011; accessed: 13.4.2015).

Beken, Münir Nurettin (2003). »Aesthetics and Artistic Criticism at the Turkish Gazino. In: Music \& Anthropology. Journal of Musical Anthropology of the Mediterranean 8; http://www.umbc.edu/MA/index/number8/gazino/bek_00. htm (accessed: 13.4.2015).

Burkhalter, Thomas (2012). »Weltmusik 2.0: Musikalische Positionen zwischen Spass- und Protestkultur. «In: Out of the Absurdity of Life. Ed. by Theresa Beyer and Thomas Burkhalter. Deitingen: Traversion, pp. 28-46.

Diederichsen, Diedrich (2014). Über Pop-Musik. Köln: Kiepenheuer \& Witsch.

Doğtaș, Gürsoy / Labastida, Alejandra (eds.) (2014). The Politics of the Melancholic Voice. Zeki Müren's Kahir Mektubu; http://issuu.com/independentcurators international/docs/m_ren_small/1 (accessed: 13.4.2015).

Erol, Ayhan (2010). "Controlling National Identity and Reshaping Public Taste: The Turkish State's Music Policies in the 1920s and 1930s.« In: Musicology Today 7 (Music Traditions in Totalitarian Systems), pp. 138-161.

Hardt, Michael / Negri, Antonio (2000). Empire. Cambridge MA: Harvard University Press.

Hey (1973ff.). Istanbul: Milliyet.

Köksal, Serhat (2012). »Interview Request for The Wire Magazine. « In: 2/5BZ; http: //2-5bz.tumblr.com/post/30514574044/2-5bz-wire-magazine-341-july-2012-inte rview (accessed: 13.4.2015).

Lund, Holger (2011). »The aesthetics of imperfection and hybridization - what is so interesting about Turkish funk and pop music of the 1960ies and 1970ies? « In: oscillation series. sonic theories and practices, http://www.shintaro-miyazaki. $\mathrm{com} / \mathrm{arch} /$ sonictheory/index- $\mathrm{p}=474$.html (accessed: 13.4.2015).

Lund, Holger (2013). »Anatolian Rock: Phenomena of Hybridization.« In: norient. com, http://norient.com/academic/anatolian-rock (accessed: 13.4.2015).

Özbek, Meral (1997). »Arabesk Culture: A Case of Modernization and Popular Identity. « In: Rethinking Modernity and National Identity in Turkey. Ed. by Sibel Bozdoğan and Reșat Kasaba. Washington, D.C.: University of Washington Press, pp. 211-233.

Potuoglu-Cook, Oyku (2008). Night Shifts: Moral, Economic, and Cultural Politics of Turkish Belly Dance Across the Fins-de-siecle. Diss. Northwestern University, Evanston, IL (Ann Arbor, MI: UMI Dissertations Publishing). 
Remise, Antoine (2014). »Turkish Psychedelic Delights.«In: Time Out Istanbul, January; http://www.timeoutistanbul.com/en/music/article/2782/Turkis (accessed: 13.4 .2015$)$.

Spicer, Daniel (2011). »Turkish Psychedelic. In: The Wire 12:334, pp. 42-49.

Skoog, Gabriel (2012). On Strange Shepherds, Golden Microphones, and Electric Guitars: Genre, Scene, and the Rise of Anadolu Pop in the Republic of Turkey. Diss. University of Washington; http://pqdtopen.proquest.com/pqdtopen/doc/ 1013766191.html?FMT=ABS (accessed: 13.4.2015).

Stokes, Martin (1999). "Sounding Out. The Culture Industries and the Globalization of Istanbul." In: Istanbul. Between the Global and the Local. Ed. by Caglar Keyder. Oxford: Rowman and Littlefield, pp. 121-139.

Stokes, Martin (2000). "East, West, and Arabesk. «In: Western Music and its Others: Difference, Appropriation and Representation in Music. Ed. by Georgina Born and David Hesmondhalgh. Berkeley, CA: University of California Press, pp. 213233.

Stokes, Martin (2003). »The Tearful Public Sphere: Turkey's >Son of Art<, Zeki Müren. «In: Music and Gender: Perspectives from the Mediterranean. Ed. by Tullia Magrini. Chicago, IL: University of Chicago Press, pp. 307-328.

Stokes, Martin (2010). The Republic of Love: Cultural Intimacy in Turkish Popular Music, Chicago, IL: University of Chicago Press.

Tekelioğlu, Orhan (2001). »Modernizing reforms and Turkish music in the 1930s.« In: Turkish Studies 2:1, pp. 93-108.

Thorne, Sam (2011). »From the Ottoman Diaspora to the Musical Influence of the Eastern Mediterranean: The Early Days of the Record Industry in New York. «In: frieze 143, November-December; http://www.frieze.com/issue/article/music9 (accessed: 13.4.2015).

Uyar, Cadğas (2006). Liner notes to Bunalım - Bunalım, Shadoks Music, Shadocks 078.

\section{Videography}

Bulut, Gökhan / Kaya, Cem (2010). Arabesk. From Street Sound to Mass Culture / alternative title: Arabesk - Gossensound und Massenpop. Germany/Turkey, 58min., arte/zdf, broadcast on Arte, 30. September. On: http://alkislarlayasi yorum.com/icerik/85281/arabesk-belgesel-56-dk (accessed: 13.4.2015).

Bulut, Hakki (1975). »Nedir Bende Olmayan.« On: http://www.zapkolik.com/video /hakki-bulut-nedir-bende-olmayan-846066 (accessed: 13.4.2015).

Gencebay, Orhan (1971). »Hor Görme Garibi.« On: http://www.youtube.com/ watch?v=y5YFjYSJyA8 (accessed: 13.4.2015).

Gencebay, Orhan (1975). »Bir Araya Gelemeyiz.« On: https://www.youtube.com/ watch?v=MoPdKFRp7bs (accessed: 6.7.2015).

Gencebay, Orhan (1978). Derdim Dünyadan Büyük, Directed by Șerif Gören. On: https://www.youtube.com/watch?v=XUZQ4jT95PE (accessed: 13.4.2015).

Karaca, Cem (1971). »Demedim Mi.« On: http://www.youtube.com/watch?v= XTK8ximy1-I (accessed: 13.4.2015).

Koray, Erkin / Ter (1972). »Hor Görme Garibi.« On: http://www.youtube.com/ watch?v=W1RYl8Gf_8w (accessed: 13.4.2015).

Koray, Erkin (1976). »Sevdiğim. « On: https://www.youtube.com/watch?v=YaDEtND GIZI (accessed: 6.7.2015). 


\title{
Discography
}

Bulut, Hakki (1975). »Nedir Bende Olmayan.« İstanbul Plak 9315.

Gencebay, Orhan (1971). »Hor Görme Garibi.« İstanbul Plak 9180.

Gencebay, Orhan (1975). »Bir Araya Gelemeyiz. "Kervan Plakçılık K. 95.

Heino (2013), Mit freundlichen Grüßen. Starwatch Entertainment 88725460671.

Karaca, Cem (1971). »Demedim Mi.« Türkofon 1017.

Koray, Erkin / Ter (1972). »Hor Görme Garibi.« İstanbul Plak 9142.

Koray, Erkin (1976). »Sevdiğim. « Kervan Plakçılık 114.

Tatasopoulos, John (1975). »Bouzoukia solo.« On: V/A - Alla Turka, alternativly named Music For Belly Dancing - The Turkish Way with Özel. Murray Hill Records 4332.

\begin{abstract}
Like many countries, Turkey was hit by the wave of Anglo-American pop-rock music in the 1950s and 1960s. This led to the birth of Anatolian Rock, Arabesk, and Belly Dance. The specific qualities of these styles seem to be rooted in the unique situation of the Turkish music scene. This had to do with the people involved: they mixed and mingled, ignoring social boundaries to a surprising extent, producing musical syntheses consisting of unpredictable combinations. The main place for this kind of musical practice was the gazino, a special venue, with its open-minded musical programming. This article examines the acting agents and their styles. Although each addressed a very different audience, the styles were freely combined, for example in Arabesk Rock as a mixture of Anatolian Rock and Arabesk. How could these hybrids be created, despite of the music-sociological paradoxes in style and audience? It seems there was a special Turkish pop-rock logic at work, which had the gazino at its heart.
\end{abstract}

